\title{
COMPARISON OF AGRICULTURAL SITUATION OF INDIA FOR TWO YEARS (2017 AND 2018) USING VARIOUS DROUGHT ASSESSMENT INDICATORS DURING SOUTH WEST MONSOON SEASON IN INDIA
}

\author{
Shalini Saxena*, K. Choudhary, R. Saxena, A. Rabha, Preeti Tahlani and S. S. Ray \\ Mahalanobis National Crop Forecast Centre, DAC\&FW, Pusa, New Delhi-110012, India - (shalini.85, karan.c)@gov.in, \\ (rajatgun, rabhaamit)@gmail.com, preeti.tahlani@gov.in, shibendu.ncfc@nic.in
}

Commission III, Working Group III/10

Key Words: Agriculture Drought, NDVI, Rainfall, Dry Spell, Trigger

\begin{abstract}
:
Agricultural drought is concerned with the soil moisture deficiency in relation to meteorological droughts and climatic factors and their impacts on agricultural production and economic profitability. Present study is based on two years kharif seasons i.e. 2018 and 2017, comparison of drought assessment using remote sensing, soil moisture indices, rainfall and crop sown area as per the New Drought Manual, December, 2016. The drought assessment was carried out at district and sub-district level under National Agricultural Drought Assessment and Monitoring System (NADAMS) project. Drought trigger-1 is checked with rainfall deviation and dry spell. During 2017, the final drought categories were defined on the basis of Rainfall, Moisture and Vegetation Condition Index. During 2018, the final district level drought categories are defined using 3 indicators, where sown area upto end of August was also considered. Based on the approach defined in the New Drought Manual, analysis was carried out at district level for 17 major agricultural drought prone states of the country. State wise Rainfall deviation, dry spell, NDVI/NDWI situation was compared for both the years. Remote sensing based vegetation and water indices are important impact indicator out of 4 because it gives an idea of crop profile and surface wetness condition respectively. Thus the present study is an attempt to compare the drought situation in kharif season of years 2017 and 2018 on the basis of different impact indicators.
\end{abstract}

\section{INTRODUCTION}

Drought is temporary reduction in moisture availability significantly below the normal amount for a specific period. In general, Drought is extreme hydrologic event causing shortfall of moisture which persist long enough to trigger detrimental effects on human, vegetation, animals and ecosystem. Based on the criteria, drought is broadly categorized into meteorological drought, hydrological drought, agricultural drought and socioeconomic drought. The availability of water in surface waterbodies reduces significantly during the drought year. The groundwater table declines and the wells, especially shallower ones, dry up. Sometimes, the concentrations of salts and toxic elements such as arsenic, fluoride and nitrate also increase in the groundwater (NAAS, 2011; Gautam, 2012).

Agricultural drought is a period of dryness affecting the soilmoisture status and preventing the growth of plants. Drought creates a condition when the amount of water needed for transpiration and evaporation exceeds the total amount of moisture available in soil. It is the result of the moisture stress in soils and plants during crop growth (Reddy, 2008). In India, crops grown under arid and semi- arid conditions are often prone to the situations of agricultural drought (Gupta, 1992). The Indian sub-continent is influenced by South-West (S-W) monsoon during June-September and North-East (N-E) monsoon during October-December. Nearly $70 \%$ of the annual rainfall in India is received during the $\mathrm{S}-\mathrm{W}$ monsoon (Saxena, 2012). To define, drought is considerd to have occurred over an area where the annual average rainfall is less than $50-75 \%$ of the normal south-west (S-W) monsoon rains. Delayed onset of S- W monsoon rains or early receding of monsoon rains or long gaps between 2 heavy and effective rains during rainy season are the general phenomenon of agricultural drought in India.

*Corresponding Author
Since a large zone are dependent on the kharif season agriculture production. The intensity of drought may be moderate or severe depending on the deviations of seasonal rainfall. In other words, it commences with the inability of plant roots to obtain soil moisture rapid enough to maintain the internal water balance of the crop (Gupta, 1992). Distribution of rainfall also counts in determining the drought (Reddy, 2008). Since the year 2012, the Mahalanobis National Crop Forecast Centre (MNCFC) of Department of Agriculture, Cooperation \& Farmers Welfare (DAC\&FW), has been carrying out agricultural drought assessment using satellite, meteorological and ground based data, under the NADAMS (National Agricultural Drought Assessment and Monitoring System) project, using the technology developed by National Remote Sensing Centre, ISRO (Ray et al., 2014). District and subdistrict level drought were being assessed for 14 major agricultural drought prone states (Andhra Pradesh, Bihar, Chhattisgarh, Gujarat, Haryana, Jharkhand, Karnataka, Madhya Pradesh, Maharashtra, Odisha, Rajasthan, Tamil Nadu, Telangana and Uttar Pradesh).

In December, 2016, the new drought manual was published by DAC\&FW, Ministry of Agriculture \& FW, Government of India (DAC\&FW, 2016). The drought assessment procedure was changed. The procedure involved 3 levels. In the first level, the rainfall deviation (or Standardized Precipitation Index, SPI) and the dry spell are checked to decide, whether the Trigger 1 is YES. For the areas, where Trigger 1 is YES, 3 out 4 impact indicators (Crop, Remote Sensing, Soil Moisture and Hydrology) are checked to assess the severity of drought situation (Trigger 2). If Drought situation is Severe/ Moderate, the state government needs to carry out ground truth for verification.

Based on this procedure, MNCFC has carried assessment of Trigger 1 (Rainfall) and Trigger 2 (Impact Indicators), at district level for 17 states (above 14 states plus Punjab, West Bengal 
and Assam). The current article presents the comparative study of drought situation in kharif seasons of $2017 \& 2018$.

\section{STUDY AREA}

MNCFC has carried out assessment of Trigger 1 at district level for 17 states Assam, Andhra Pradesh, Bihar, Chhattisgarh, Gujarat, Haryana, Jharkhand, Karnataka, Madhya Pradesh, Maharashtra, Odisha, Punjab, Rajasthan, West Bengal, Tamil Nadu, Telangana Uttar Pradesh and Trigger 2 taluk level assessment in 14 states except Assam, Punjab and West Bengal. Study states are given in Figure 1.

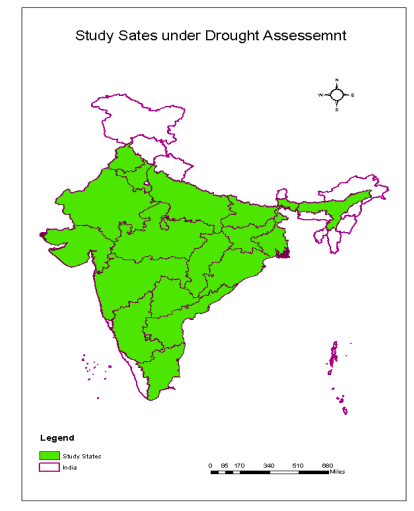

Figure 1: Study Area

\section{DATA USED}

During the year 2017 \& 2018, assessment of Drought Indicators was carried out with multiple indices/data i.e. 1) Normalized Difference Vegetation Index (NDVI) derived from Resourcesat 2- AWiFS (56m spatial resolution) and MODIS (250m spatial resolution), 2) Normalized Difference Wetness Index (NDWI) derived from MODIS (250 m) data, 3) Soil water balance based Percent available Soil Moisture (PASM) in which the daily near real time spatial rainfall product from Climate Prediction Centre (CPC) of NOAA and the daily global Potential Evapotranspiration (PET) data are used as the rainfall and climatic input, respectively. The soil information has been derived from the 1:0.5 M scale soil map of NBSS\&LUP., 4) District-level Weekly Rainfall data from IMD. The weekly rainfall deviations are used to compute monthly and cumulative rainfall deviation and the Dry spell, 5) Standardized Precipitation Index derived from NOAA CPC gridded (0.50x0.50) Precipitation data (year 1979-2018), 6) State level Crop sown area is taken from Crops Division, DAC\&FW, 7) District level Irrigations Statistics collected from the land use statistics of Directorate of Economics \& Statistics, DAC\&FW (http://lus.dacnet.nic.in/dt_lus.aspx), 8)Reservoir Storage Position Data regarding the status of major Reservoirs storage was taken from the Central Water Commission (CWC) website.

(http://www.cwc.nic.in/newsite/Reservoir Monitoring.html).

\begin{tabular}{rlll}
\hline SI.No. & Indices & Data Used & Level \\
\hline 1. & NDVI/ & MODIS-Terra/ & District/Taluk \\
& NDWI & $\begin{array}{l}\text { Resourcesat-2 } \\
\text { AWiFS }\end{array}$ & Wise \\
2. & PASM & $\begin{array}{l}\text { Using soil } \\
\text { moisture model }\end{array}$ & District Wise \\
3. & Dry Spell & IMD Rainfall & District wise \\
\hline
\end{tabular}

\begin{tabular}{llll}
\hline 4. SPI & $\begin{array}{l}\text { Data } \\
\text { NOAA CPC } \\
\text { Rainfall }\end{array}$ & District wise \\
\hline
\end{tabular}

Table 1: Details of satellite data products used in the study 4. METHODOLOGY

Methodology has been defined in Figure 2. The various impact indicators used in study are discussed as follows.

\subsection{Vegetation Index Image}

NDVI is derived using the formula (NIR - Red) / (NIR + Red) where Red and NIR are the reflectance in visible and near infrared channels. The NDVI values for vegetation generally range from 0.2 to 0.6 , the higher index values being associated with greater green leaf area and biomass.

\subsection{Surface wetness indicators}

Shortwave Infrared (SWIR) band is sensitive to moisture available in soil as well as in crop canopy. NDWI $=($ NIRSWIR) / (NIR+SWIR) Where, NIR and SWIR are the reflected radiation in Near-Infrared and Shortwave Infrared channels. Higher values of NDWI signify more surface wetness.

\subsection{NDVI Deviation using AWiFS data}

NDVI images generated from Resoursesat 2-AWiFS satellite data is compared with the recent normal year. Simple relative deviation is calculated between the current year and recent normal year. Normal year is different for different states.

\subsection{Percent Available Soil Moisture (PASM)}

A water balance model has been developed, by National Remote Sensing Centre, to derive the top $30 \mathrm{~cm}$ profile soil moisture (Chandrasekar et al., 2015). PASM is based on daily water balance and is defined as the ratio of the difference between the current soil moisture (SMc) and the permanent wilting point (PWP) to the field capacity (FC) and the Permanent wilting Point. The index values range from 0 to 100 with 0 indicating extreme dry condition and 100 wet conditions.

\subsection{Standardized Precipitation Index}

The computation of SPI requires long term data on precipitation to determine the probability distribution function (gamma distribution, as the gamma distribution has been found to fit the precipitation distribution quite well) which is then transformed to a normal distribution with mean zero and standard deviation of one. Thus, the values of SPI are expressed in standard deviations, positive SPI indicating greater than median precipitation and negative values indicating less than median precipitation (Edwards and McKee, 1997). For generating SPI long term NOAA CPC gridded (0.50x0.50) Precipitation data (year 1979-2018) has been used.

\section{RESULTS AND DISCUSSION}

On the basis of above described approach the agriculture drought situation for both the year (2017 \&2018) are compared. The trigger and impact indicators are checked and briefed here: 


\subsection{Cumulative Rainfall situation of Pan India during $1^{\text {st }}$ June to $30^{\text {th }}$ September 2017 \& 2018}

A per the IMD, during year 2017, monsoon onset over Kerala was on 30th May and in 2018 it was on $29^{\text {th }}$ May. During 2017, the rainfall received till end of September month was normal or excess in majority of Met. Sub-divisions (30 out of 36), Deficient in 6 Meteorological Sub-divisions (East Uttar Pradesh, East Madhya Pradesh, Har. Chd. \& Delhi, Punjab, Vidarbha, and West Uttar Pradesh). Total rainfall for the country as a whole upto 30th September 2017 was below normal by $5 \%$. The actual rainfall was $841.3 \mathrm{~mm}$ against the normal of $887.5 \mathrm{~mm}$. The cumulative rainfall in the country during the monsoon season i.e. 01st June, 2018 to 26th September, 2018 has been $9 \%$ lower than LPA. Out of 36 met sub-divisions, 12 met subdivisions constituting $32 \%$ of the total area of the country has received deficient/large deficient rainfall. District wise weekly rainfall deviation during June, July, August and September 2018 showed that during $14^{\text {th }}$ to $20^{\text {th }}$ June, $26^{\text {th }}$ July to $1^{\text {st }}$ August and $2^{\text {nd }}$ to $8^{\text {th }}$ August 2018, major part of the country is at deficient and scanty rainfall.

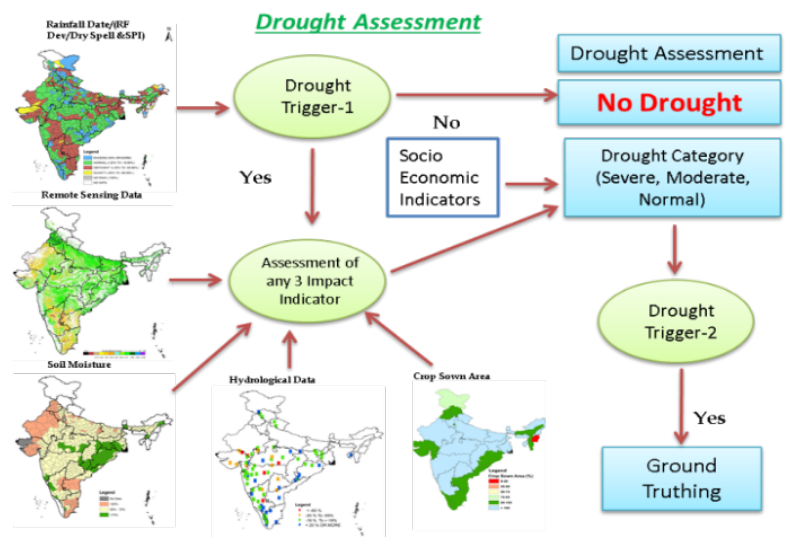

Figure 2: Flow Chart of Methodology for Drought assessment

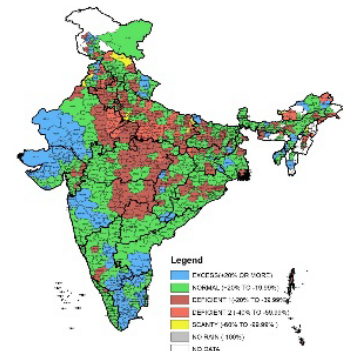

Fig 3. Cumulative Rainfall situation of Pan India during

$1^{\text {st }}$ June to $30^{\text {th }} \operatorname{Sep} 2017$

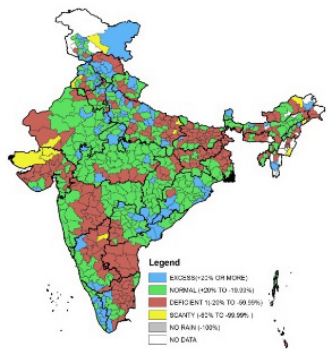

Fig 4. Cumulative Rainfall situation of Pan India during $1^{\text {st }}$ June to $30^{\text {th }}$ Sep 2018
Most of the states are showing normal to excess rainfall except Indo-Gangetic region and Tamil Nadu, Rayalseema regions during 16th to 22nd August 2018. Indo-Gangetic region received excess rainfall during 30 August to 05th September 2018. During $13^{\text {th }}$ to $19^{\text {th }}$ September, the most of the parts of india received deficient to scanty rain which again received excess rain during 20th to 26th September 2018. During June 2018, major part of Uttar Pradesh, Bihar, Jharkhand, Odisha and Gujarat had scanty and deficient rainfall, which recovered during July \& August. However, many district of Gujarat, Rajasthan, Tamil Nadu, Andhra Pradesh (Rayalseema), North interior Karnataka, Bihar, Jharkhand and Uttar Pradesh had deficient rainfall, in comparison to the number of districts having deficient rainfall till 30th September 2018 which was comparatively low in 2017 (Fig 3\&4)

\subsection{Dry Spell during $1^{\text {st }}$ June to $30^{\text {th }}$ Sep $2017 \& 2018$}

Using the weekly rainfall deviation Dry Spell, districts having scanty rainfall and districts with the Trigger-1 Yes were identified. Dry spell was considered to be 'yes' for the districts those received more than $50 \%$ deficiency in rainfall during three consecutive weeks for light soil regions and four weeks for heavy soil regions. Scanty rainfall was 'Yes' for the districts those were received more than $60 \%$ deficient rainfall during the month of September. Districts having more than $50 \%$ deficient rainfall are higher during September 2018 as compared to September 2017 (Fig 5\&6).

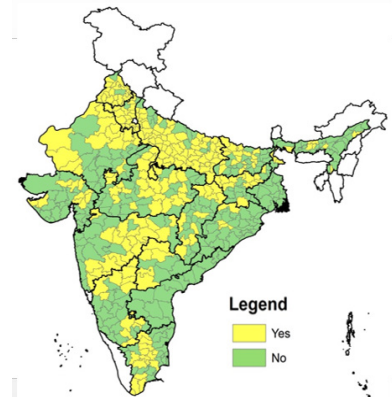

Fig 5. Dry spell JuneSeptember 2017

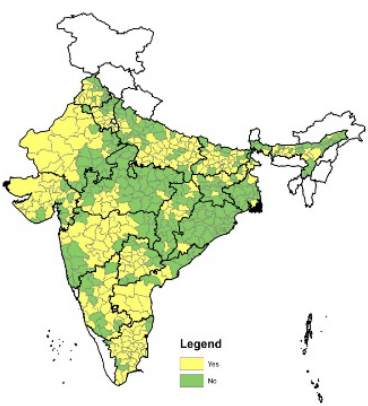

Fig 6. Dry Spell JuneSeptember 2018
6 districts of Gujarat were having more than $50 \%$ deficient rainfall which was nil in Gujarat during this period. By the end of September, among 553 districts in 17 states, 282 districts had Dry spell, 20 districts under the class of less than $50 \%$ of rainfall and 9 districts (Banaskantha, Kachchh, Patan (Gujarat), Yadgir (Karnataka), Fazilka (Punjab), Firozpur (Punajb), Jalore (Rajasthan), Kushinagar, Mau (Uttar Pradesh) had scanty rainfall. Combining all these, as shown in Figure 1, total 284 districts in 17 states were found to have Trigger 1 ON (Figure 4). These districts mostly belonged to Andhra Pradesh (8), Assam (14), Uttar Pradesh (36 districts), Bihar (27), Chhatisgarh (10), Gujarat (23), Haryana (15), Jharkhand (9), Karnataka (19), MP (12), Maharasthra (21), Odisha (1), Punjab (12) Rajasthan (16), and Tamil Nadu (26), Telengana (21), UP (45) and West Bengal (5). Out of 284 districts with Trigger 1 (Rainfall) YES, 25 districts are having both the impact indicators Severe, Whereas 20 districts are having one severe and one moderate category. 12 districts are under moderate category. In 214 districts both the indicators are having one severe/moderate and one normal/mild category. 13 districts are under Normal/Mild category. However, Three districts (Kachchh, Porbandar and Devbhoomi Dwarika) not assessed due to PASM data is not available. Compared to this, in 2017 by the end of the of August month, there were 284 districts with the Trigger 1 (Rainfall) YES, Out of these no district was having both the Impact Indicators in the Severe Category, 4 districts are having both the indicators in Moderate Category, 50 districts having one indicator in Severe/Moderate Category \& one indicator in Normal/Mild Category and 230 districts had both the Impact Indicators in Normal/Mild Category (Fig 7\&8). 


\subsection{Vegetation Index Image}

The vegetation index image of the country derived from Resourcesat 2- AWiFS (56m) satellite data for September 2017 $\& 2018$ after overlaying the non-agriculture mask. Current year NDVI images shows that NDVI values are lower as compared to last year most of the states except Punjab, Northern \& Eastern Bihar and West Bengal and Assam. Few districts of Uttar Pradesh Haryana, Assam are showing higher NDVI with respect to last year (Fig 9-14)

The figure 13 represents the NDVI profiles of Rajasthan, Karnataka, Gujarat and Jharkhand in comparison to NDVI of previous year till the first fortnight of October 2018. In the study, NDVI profiles showed that the poor vegetation condition was observed in states of Andhra Pradesh and Tamil Nadu as compared to last year. Other states are showing average vegetation condition as compared to previous years. The vegetation condition of Bihar, Chhattisgarh, Haryana, Jharkhand, Odisha and Punjab improved during September 2018.

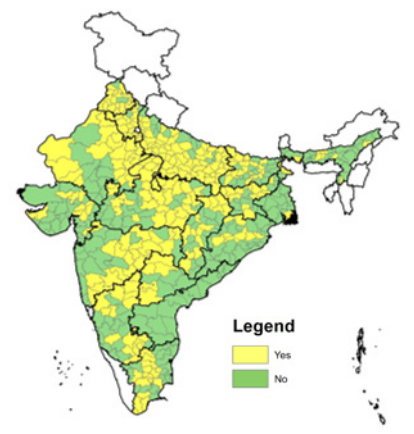

Fig 7. Trigger-1 upto 30th September 2017

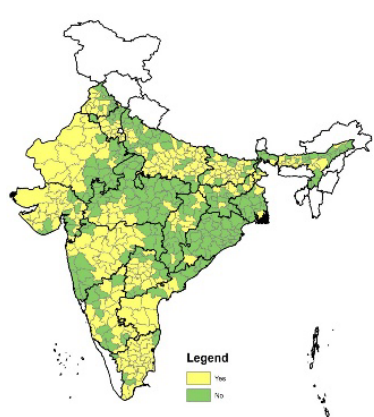

Fig 8. Trigger-1 upto 30th September 2018

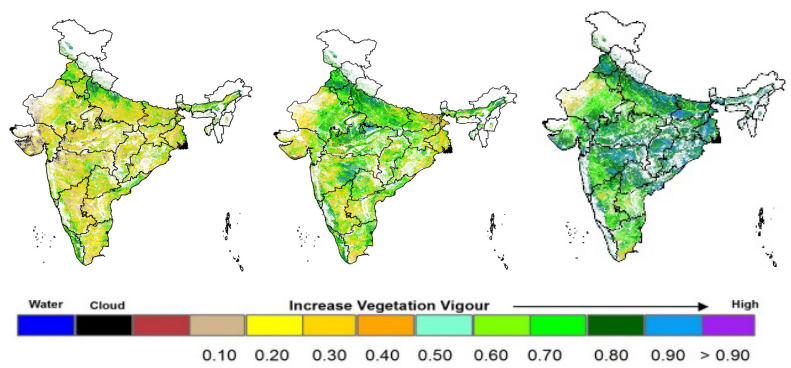

Fig 9. NDVI July 2017
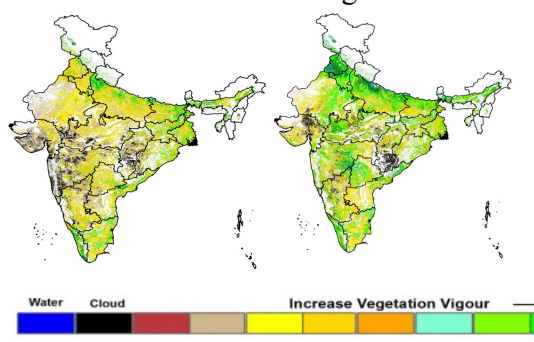

Fig 12. NDVI July 2018

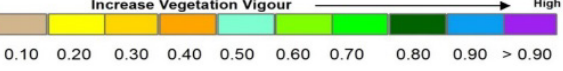

Fig 13. NDVI August 2018

Fig 14. NDVI
Fig 11. NDVI

September 2017

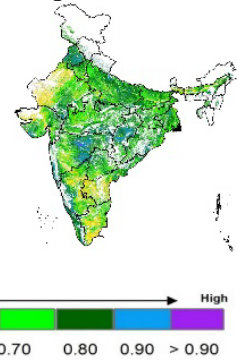

September 2018
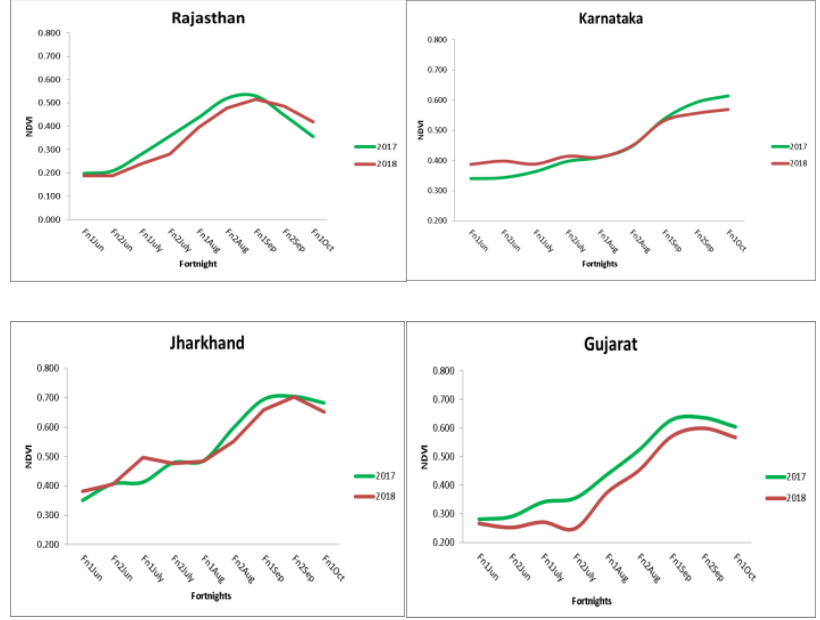

Figure 13. Sate wise comparison of NDVI profiles (kharif season) for most drought prone states of India

\subsection{Standardized Precipitation Index (SPI)}

SPI map for the period of 1 st June to $31^{\text {st }}$ September 2018 showed moderately to severely dry regions in parts of Gujarat, Karnataka, Rayalseema region of Andhra Pradesh, Telangana, Gujarat, and Bihar and major Mildly Dry region in the state of M.P, Gujarat, Chhattisgarh, Odisha, Tamil Nadu, Rajasthan and Assam. In comparison to that, the SPI of similar period in 2017, more dry area in the central part of the country. (Fig 15 \& 16)

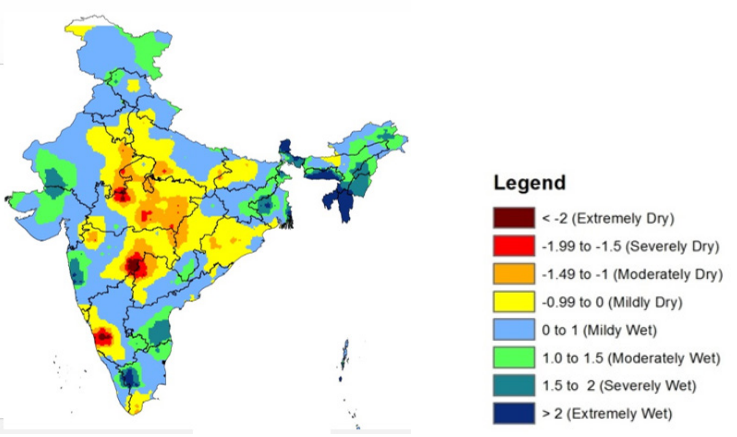

Fig.15 Upto September 2017

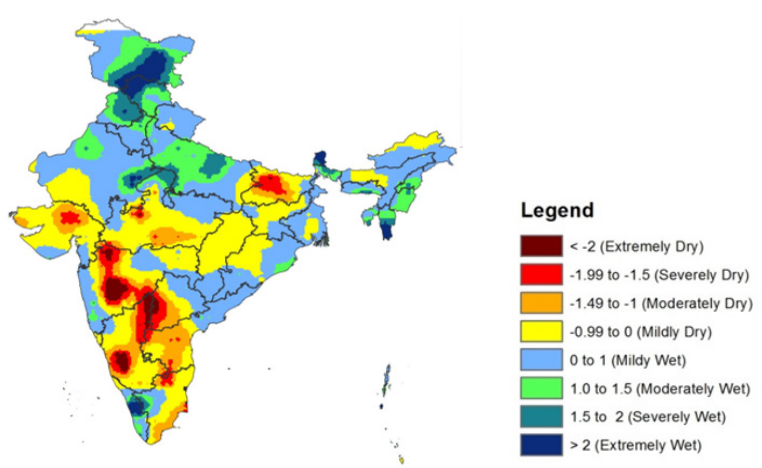


Fig 16. Upto September 2018

\subsection{Surface Wetness Indicators}

The Wetness index image of the country for September 2018 after overlaying non-agriculture area mask is shown in Fig 2021. It has been compared with last year wetness index image (Fig 17-19)

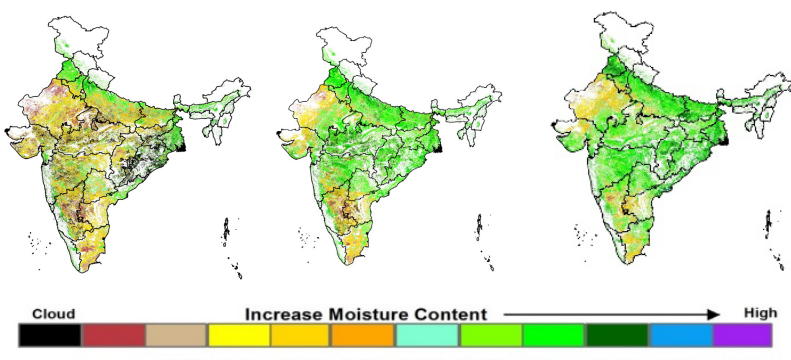

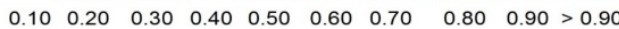
Fig 17. NDWI Fig 18. NDWI Fig 19. NDWI July $2017 \quad$ August $2017 \quad$ September 2017
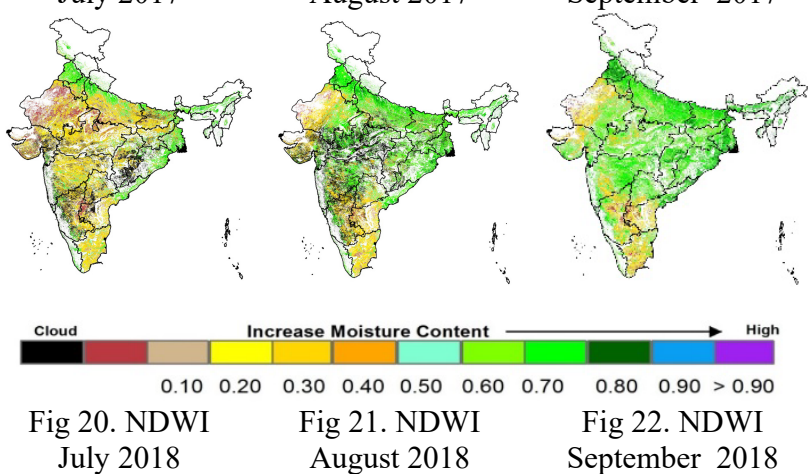

As compared to the last year, current year NDWI image shows that NDWI values are lower in the northern and western parts (Gujarat, Rajasthan,) and in Southern parts (A.P, Karnataka, Telengana, Tamil Nadu). Some districts of Punjab, Uttar Pradesh and Assam are having higher values of water index as compared to last year. (Fig 17-22)

\subsection{Percent Available Soil Moisture (PASM)}

Average Percent Available Soil Moisture (PASM) for the month of September shows that PASM values are below $50 \%$ in states of Gujarat, Rajasthan, Haryana, Punjab, Andhra Pradesh, Tamil Nadu, few districts of Karnataka and Uttar Pradesh. Majority of districts of Odisha, Chhattisgarh, Jharkhand, Karnataka are having PASM $>75 \%$ upto end of September 2018. During the year 2017, soil moisture was calculated on the basis of MAI (Moisture Adequacy Index).

\subsection{District Level Irrigated Area}

District level irrigated Area is presented in Fig $23 \& 24$ for the year $2017 \& 18$ respectively which shows that in States like Punjab, Haryana and Uttar Pradesh, majority of the districts are having more than $75 \%$ of area under irrigation, whereas in the states like Maharashtra, Chhattisgarh, Jharkhand, Odisha, Kerala, Uttarakhand, Himachal Pradesh and North Eastern States majority of the districts are having less than $25 \%$ of area under Irrigation.

\subsection{Crop Sown Area \& Ground Survey}

As per the crop weather watch group latest report, sowing of kharif crops, around $96.5 \%$ of the normal area under Kharif crops has been sown upto 30.09.2018. As per 1st Advance Estimates for

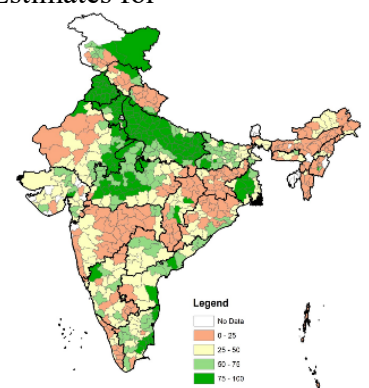

Fig 23. Irrigated area map 2017

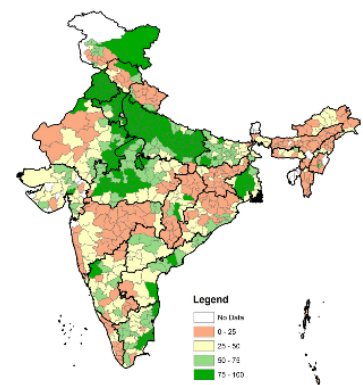

Fig 24. Irrigated area 2018
2018-19, the area coverage under all Kharif crops taken together has been 1052.38 lakh hectares at all India level as compared to 1072.79 lakh hectares during 2017-18. Area covered in majority of the states are more than $85 \%$ of the total season normal except Manipur which showing area coverage less than $25 \%$.

Ground survey for 12 states under NADAMS was planned during month of September 2018 to collect the crop soil system information. State Remote Sensing Centres (Andhra Pradesh, Chhattisgarh, Haryana, Uttar Pradesh, Karnataka, Maharashtra and Telangana) collected ground truth information from the districts/taluks having severe category of PASM and NDVI/NDWI deviation. The field photographs were also collected from different parts of the country. Rainfall situation, Soil moisture, Crop health, approximated crop loss percentage was observed during the field visit. As per ground data, it is found that kharif paddy is in maturity stage in Chhattisgarh, UP, Maharashtra, Karnataka, AP states but the soil moisture condition is mostly dry. A poor soil and cotton, groundnut health condition was found in Karnataka and Gujarat. Kharif paddy and cotton crop was under good an improving condition in Haryana. In Haryana July and August month was dry as per GT data but due to heavy rain during 2nd fortnight of September soil health got improved.

\subsection{Analysis of Drought Indicators}

District-wise analysis in 17 states, by the end of September 2018 showed that there are 284 Districts with the Trigger 1 (Rainfall) YES, In 13 states (Andhra Pradesh, Chhattisgarh, Haryana, Karnataka, Jharkhand, Madhya Pradesh, Maharashtra, Punjab, Gujarat, Rajasthan, Odisha, Telangana, Uttar Pradesh), three indicators i.e. NDVI/NDWI deviation, Soil Moisture and Sown Area are used to assess the final drought condition. And in rest of the 4 states only two parameters are used to check the assessment. Out of 17 States all Districts of 4 states were classified into following 6 categories due to unavailability of data with MNCFC, only 2 impact Indicators (Remote Sensing and Soil Moisture) were assessed and in 13 states were classified into following 9 categories on the basis of three impact indicators i.e. Remote Sensing, Soil Moisture and Crop Sowing. Trigger 1 is found YES in 284 districts out of 553 districts (17 states). Trigger 1 is No was found in 269 districts. Assam, Bihar, Tamil Nadu, and West Bengal are the states 
where two indicators (NDVI/NDWI deviation) and PASM are estimated.

For 4 states the categories are given below:

1. Trigger 1 is Yes (71 districts)

2. Both Impact Indicators Severe (No districts)

3. One Severe \& One Moderate (04 districts)

4. Both Moderate (03 district)

5. One Severe/Moderate \& One Normal/Mild (64 districts)

For rest of the 13 states the 9 Categories are as follows:

1. Trigger 1 is Yes (209 districts)

2. All three Impact Indicators Severe (05 districts)

3. Two Severe and One Moderate (03 districts)

4. Two Severe and One Normal (01 districts)

5. Two Moderate and One Severe (04 districts)

6. One Severe One Moderate \& One Normal (09 districts)

7. Two Moderate and One Normal (17 districts)

8. Two Normal and One Moderate (112 districts)

9. Two Normal and One Severe (45 districts)

10. All three Impact Indicators Normal (07 districts)

11. Three districts (Kachchh, Porbandar and Devbhoomi Dwarika) not assessed due to PASM is not available.

Hence according to the assessment of drought indicator till the month of September 2018, it is observed that the states where three indicators are used, the severe drought situation is observed in state of Andhra Pradesh (4 districts), Karnataka (03 districts), Rajasthan (01 district, Jalore) whereas in Andhra Pradesh, Karnataka, Rajasthan, Jharkhand, MP, Maharashtra, Telangana, Uttar Pradesh and Gujarat state are under moderate drought situation (Fig 26)
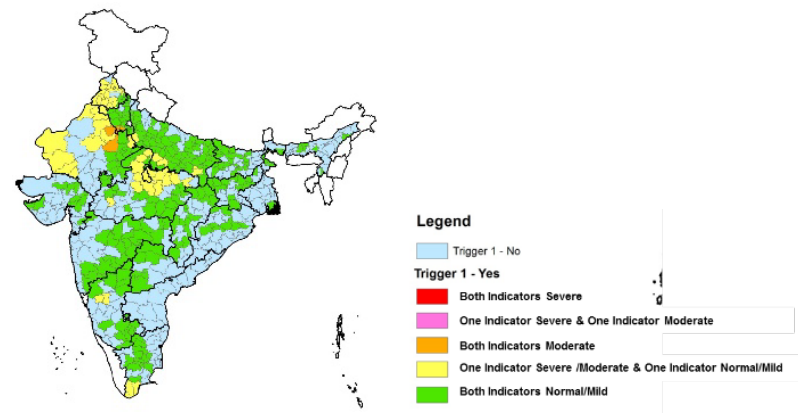

Fig 25. Drought Assessment map 2017
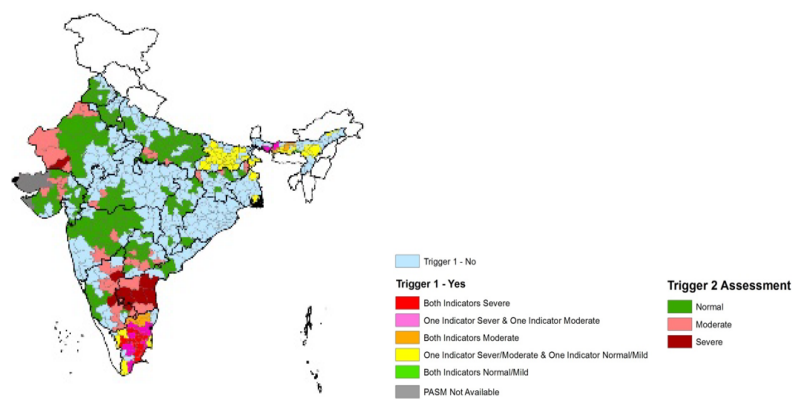

Fig 26. Drought Assessment map 2018

Final drought assessment analysis shown that in Andhra Pradesh, 4 districts Ananthpur, Nellore, Cuddappah and Prakasam are under severe drought condition. In Chhattisgarh and Haryana the drought situation is normal. In Karnataka 3 districts Chikballapur, Chitradurga, Raichur are under severe and three under moderate drought condition. In Aurangabad in Maharashtra is showing severe drought condition. Where as in Telangana 6 districts are under moderate drought situation. If compared it with district-wise analysis in 17 states, by the end of September 2017, it showed that there are 284 Districts with the Trigger 1 (Rainfall) YES, out of which no District is having both the Impact Indicators in the severe Category, no district is having one indicator in Moderate and one indicator in Severe category, 4 Districts are having both the indicators in Moderate Category (Mahendragarh, Rewari, Jaipur, Jhunjhunu), 54 Districts having One indicator in Severe/Moderate Category \& One indicator in Normal/Mild Category. 230 districts out of the 284 districts had both the Impact Indicators in Normal/Mild Category.

\section{CONCLUSION}

A comparative study of kharif season drought of India for the year 2017 \& 2018 showed that in most of states drought situation was there even if onset of monsoon during 2018 was normal. The reason of drought situation is majorly due to long dry spells during month of July and August, as a result the delay in transplanting of kharif paddy, stunted growth of kharif season crops and water scarcity in reservoirs.

\section{ACKNOWLEDGEMENTS}

The drought assessment was carried out under NADAMS (National Agricultural Drought Assessment and Monitoring System) project, funded under the FASAL (Forecasting Agricultural output using Space, Agro-meteorology and Land based observations) of Department of Agriculture, Cooperation \& Farmers Welfare (DAC\&FW). The authors are thankful to the senior officials of DAC\&FW for their strong support and keen interest in the work. The input data taken from various agencies (IMD, CWC, Crops Division of DAC\&FW, State Governments, NOAA-CPC, NASA-MODIS, NRSC-NDC) is acknowledged. The Drought Assessment team is also thankful to JS(IT) and JS(DM). DAC\&FW and senior revenue/relief/disaster management officials of various states for their keen interest in the outputs generated by MNCFC.

\section{REFRENCES}

Chandrashekhar, K. \& Sesha Sai, M. V. R. (2015) Monitoring of late-season agricultural drought in cotton-growing districts of Andhra Pradesh state, India, using vegetation, water and soil moisture indices. Nat Hazards 75:1023-1046.

CWC.http://www.cwc.nic.in/newsite/ReservoirMonitoring.html . Central Water Commission.

DAC\&FW (2016) Manual for Drought Management, December 2016. Department of Agriculture, Cooperation \& Farmers Welfare, Ministry of Agriculture \& Farmers Welfare, Government of India, New Delhi, 154 p.

Gautam, R.C. 2002. Drought: Impact and Mitigation Strategies. Paper presented in the Brain Storming Session on Management of Drought, 2002 on 13 September, 2002 at National Centre for Disaster Management, Indraprastha Estate, Ring Road, New Delhi.

Gautam, R.C. and Bana, R.S. 2014. Drought in India: Its impact and mitigation strategies-A review. Indian Journal of Agronomy 59 (2):179-190 
Gupta, U.S. 1992. Drought injury and resistance of crop plants (in) Physiological aspects of dryland farming. Oxford \& IBH Publishing Co, New Delhi, p. 147-162.

Edwards, D. C., and T. B. McKee (1997) Characteristics of $20^{\text {th }}$ century drought in the United States at multiple time scales. Climatology Report No. 97-2, Colorado State Univ., Ft. Collins, CO.

NAAS. 2011. Drought Preparedness and Mitigation. Policy Paper No. 50, National Academy of Agricultural Sciences, New Delhi, pp. 22.

Ray, S. S., Sesha Sai, M. V. R. and Chattopadhyay N. (2014) Agricultural Drought Assessment: Operational Approaches in
India with Special Emphasis on 2012. In: High-Impact Weather Events over the SAARC Region (Ed. K. Ray, M. Mohapatra, B.K. Bandyopadhyay, L. S. Rathore). Springer. pp. 349-364.

Reddy, SR. 2008. Principles of crop production. Kalyani Publishers, Ludhiana, pp. 793.

Saxena, M.C. 2012. Harnessing the potential of dry areas for ensuring future food security in India. A lecture delivered as 42ndLal Bahadur Shastri Memorial Lecture at IARI, New Delhi on 16 February, 2012. 